\title{
PENGARUH EFEKTIFITAS PEMBELAJARAN GURU PAK TERHADAP PENINGKATAN NILAI AFEKTIF SISWA KASUS: SMP NEGERI 1 PEMATANGSIANTAR
}

\author{
Bangun Munte \\ bangunmunte@yahoo.com \\ Universitas HKBP Nommensen
}

\begin{abstract}
In learning process the teacher is not consequent on time and using appropriate teaching media. This research intends to find out the extend "Effectiveness of Teacher Christian Education Teaching on Improving Affective Value on Students at SMP Negeri 1 Pematangsiantar". in collecting data, the researcher gave questionnaires for 45 (fourty five) students as sample. This research applied descriptive quantitative method then in analyzing data hypothesis research and correlation of product moment pearson by giving questionnaires for variable $X$ (the effectiveness Teaching of a Christian Education Teacher) and Variable Y (Students' Affective Value). The research finding showed that Correlation ( $r$ ) was 0,57 with determination test was $32,49 \%$. To find out whether sifnificant or not the correlation coefficient on the real truth $(\alpha)=0,05$ so " $t$ " test was done by the criteria, if $t_{\text {hitung }}$ which was gained higher $(>)$ than $t_{\text {tabel }}$ on significant frequency $1-0,05$ with $d k=n-2$ so the hypothesis was accepted and $\mathrm{Ha}$ was rejected. The calculation found that $t_{\text {hitung }}>t_{\text {tabel }}(3,35>1,68)$ so the hypothesis was accepted. It means that there was effect of effectiveness teaching of Christian Education Teacher on Improving Students' Affective Value at SMP Negeri 1 Pematangsiantar.
\end{abstract}

Key Words: Effectiveness Teaching, Students' Affective Value

\begin{abstract}
ABSTRAK
Dalam pelaksanaan proses pembelajaran guru kurang konsekuen terhadap waktu dan kurangnya menggunakan media pembelajaran yang baik.Tujuan penelitian ini adalah untuk melihat sejuahmana "Pengaruh Efektifitas Pembelajaran Guru PAK terhadap Peningkatan Nilai Afektif Siswa di SMP Negeri 1 Pematangsiantar. Untuk mendapatkan data peneliti memberikan test kepada sampel sebanyak 45 orang. Penelitian ini menggunakan metode deskriptif, sedangkan analisis data yang dilakukan dalam penelitian hipotesis adalah korelasi product moment pearson dengan alat pengumpulan data adalah angket untuk Variabel $X$ (pengaruh efektifitas pembelajaran guru PAK) dan Variabel $Y$ (Nilai afektif siswa).
\end{abstract}


Dari hasil pengujian diperoleh pengujian korelasi (r) 0,57 dengan uji determinasi sebesar $32,49 \%$ dan untuk mengetahui signifikan tidaknya koefisien korelasi pada taraf nyata $(\alpha)=0,05$ maka diadakan uji "t" dengan kriteria pengujian jika $t_{\text {hitung }}$ yang didapat dari perhitungan lebih besar (>) dari t tabel pada taraf signifikan $1-0,05$ dengan $\mathrm{dk}=\mathrm{n}-2$ maka hipotesis diterima dan dalam hal lain ditolak. Dari hasil pengujian diperoleh $t_{\text {hitung }}>t_{\text {tabel }}(3,35>1,68)$, maka hipotesis diterima. Dengan demikian dapat dikemukakan Berpengaruh yang berarti antara. Pengaruh Upaya Efektifitas Pembelajaran Guru PAK terhadap Peningkatan Nilai Afektif Siswa di SMP Negeri 1 Pematangsiantar.

Kata Kunci: Efektifitas Pembelajaran, Nilai Afeksi siswa

\section{PENDAHULUAN}

Fungsi dan tujuan
pendidikan Indonesia yang
tertuang dalam Undang-Undang No. 20 Tahun 2003 pasal 3 yang berbunyi, pendidikan nasional berfungsi mengembangkan kemampuan dan membentuk watak serta peradaban bangsa yang bermartabat dalam rangka mencerdaskan kehidupan bangsa, bertujuan untuk mengembangkan potensi peserta didik agar menjadi manusia yang beriman dan bertaqwa kepada Tuhan Yang Maha Esa, berahlak mulia, sehat, berilmu, cakap, kreatif, mandiri, dan menjadi warga Negara yang Demokratis.

Dengan adanya UndangUndang Republik Indonesia, No
20 Tahun 2003 tentang Sistem Pendidikan Nasional dan Peraturan Pemerintah Republik Indonesia No 19 Tahun 2005 tentang Standar Nasional Pendidikan mengamatkan bahwa Kurikulum Tingkat Satuan Pendidikan (KTSP) jenjang Pendidikan Dasar hingga Menengah disusun oleh satuan pendidikan dengan mengacu kepada Standar Isi (SI) dan Standar Kompetensi Lulusan (KLS) serta berpedoman pada panduan yang disusun oleh Badan Standar Nasional Pendidikan (BSNP). UU No. 14 Tahun 2005 Bab IV pasal 20 (a) tentang guru dan dosen menyatakan bahwa standar prestasi kerja guru dalam 
melaksanakan

tugas

keprofesionalanya,

guru

berkewajiban merencanakan

pembelajaran, melaksanakan

proses pembelajaran yang

bermutu serta menilai dan

mengevaluasi

hasil

pembelajaran. Tugas pokok guru

tersebut yang diwujudkan dalam

kegiatan belajar mengajar

merupakan bentuk kinerja guru.

Peningkatan kinerja guru

akan berpengaruh pada

peningkatan kualitas output SDM yang dihasilkan dalam proses pendidikan dan pembelajaran. Kualitas pendidikan dan lulusan sering kali dipandang tergantung kepada peran guru dalam pengelolaan

komponenkomponen pengajaran yang digunakan dalam proses belajar mengajar yang menjadi tanggung jawabnya. Untuk dapat mencapai hasil belajar yang optimal tentunya guru harus memiliki dan menampilkan kinerja yang maksimal selama proses belajar mengajar dengan menyesuaikan perkembangan ilmu pengetahuan dan teknologi.
Untuk

mencapai pendidikan yang bekualitas maka sangat dibutuhkan suatu peran seorang pendidik/guru. Dalam hal ini lah pendidik/guru harus mengefektifkan suatu pembelajaran untuk mencapai tujuan pendidikan yang diharapkan sesuai dengan UU No 20 Tahun 2003 pasal 3.

$\mathrm{Di}$ dalam pendidikan pengajaran seorang guru sangat mempengaruhi keberhasilanya di dalam proses belajar mengajar terhadap siswa. Belajar selalu dikaitkan dengan sekolah, dan ketika itu pula akan terpikir tentang beberapa bidang studi dan ketrampilan apa yang harus dipelajari, misalnya: Pendidikan Agama Kristen, Matematika, Sastra, IImu Pengetahuan Alam (IPA), dan IImu Pengetahuan Sosial (IPS).

Sekolah sebagai lembaga pendidikan formal dalam pembelajaranya dalam hal ini guru memegang peranan penting dalam mencapai tujuan pembelajaran (1 Tes.2:7,11). Tugas Guru adalah mengajar 
yang diartikan sebagai suatu aktivitas pengorganisasian atau mengatur lingkungan sebaikbaiknya dan menghubungkan dengan siswa, sehingga terjadi proses belajar mengajar (Sadiman, 1990, h. 47).

Menurut Gagne, belajar adalah suatu perubahan tingkah laku karena hasil dari pengalaman yang diperoleh. Sedangkan mengajar adalah kegiatan yang penyediaan kondisi yang merangsang serta mengarahkan kegiatan belajar siswa untuk memperoleh pengetahuan, keterampilan, nilai dan sikap yang dapat membawa perubahan tingkah laku maupun perubahan serta kesadaran diri sebagai pribadi. Dalam interaksi belajar-mengajar, guru sebagai pendidik tidak mendominasi kegiatan, tetapi membantu menciptakan kondisi yang kondusif serta memberikan motivasi dan bimbingan agar siwa mampu mengembangkan potensi dan kreativitasnya melalui kegiatan belajar. Untuk itulah maka diharapkan agar guru dalam penyampaian materi pelajaran, harus mampu menggunakan strategi, metode, serta teknik yang tepat.

Guru mempunyai pengertian yaitu orang yang pekerjaannya atau mata pencahariannya, profesinya adalah mengajar. Disini pekerjaan mengajar sebagai profesi maka orang yang melaksanakan tugas mengajar harus memenuhi persyaratan profesional mengajar (2 Tim. 1:11). Mengajar diartikan mentransfer pengetahuan kepada anak didik dengan cara menuntun atau mendidik. Guru PAK adalah orang yang pekerjaannya mengajar pendidikan Kristen baik dalam sekolah negeri maupun swasta. Baik yang sudah ditetapkan menjadi pegawai negeri maupun yang tidak menjadi pegawai negeri, dengan memenuhi syarat guru Agama Kristen sebagai berikut yang dikemukakan oleh Homrighausen bahwa: "(1) memiliki pengetahuan yang hidup 
mengenai pokok yang diajarkan itu. (2) kecakapan untuk menimbulkan minat, motivasi, bahkan menggembirakan hati orang lain dengan pokok itu. (3) memiliki kerelaan untuk dilupakan sendiri, asal pengajarannya tetap tertanam saja dalam hidup orang didikannya.

Marthin Luther dalam buku Pendidikan Agama Kristen (14831548) menjelaskan bahwa Pendidikan Agama Kristen ialah Pendidikan yang melibatkan warga jemaat untuk belajar teratur dan tertib agar semakin menyadari dosa mereka serta bersuka cita dalam firman Yesus Kristus yang memerdekakan. Pendidikan Agama Kristen berfungsi untuk memperlengkapi mereka dengan sumber iman, khususnya yang berkaitan dengan pengalaman berdoa, Firman dan rupa-rupa kebudayaan sehingga mereka mampu melayani sesamanya termasuk masyarakat dan Negara serta mengambil bagian dengan bertanggungjawab dalam persekutuan Kristen.

Dari pendapat tersebut dapat disimpulkan bahwa Pendidikan Agama Kristen adalah supaya setiap manusia menyadari kasih Allah sebagaimana dinyatakan dalam Yesus Kristus melalui iman dan sarana yang menolong manusia untuk bertumbuh.

Guru Pendidikan Agama Kristen adalah guru yang bertanggungjawab dalam mentransfer ilmu pengetahuan yang dimilikinya kepada anak didik dan sebagai pendidik harus membentuk sikap dan perilaku anak didik sesuai dengan nilainilai Kristiani. Guru yang mendasarkan pengabdiannya karena panggilan jiwa, merasakan jiwanya lebih dekat dengan anak didiknya.

Seorang guru harus dapat membantu perkembangan aspekaspek pribadi seperti sikap, nilainilai, dan penyesuaian diri. Demikianlah, dalam proses belajar-mengajar guru tidak sebatas sebagai penyampai ilmu 
pengetahuan akan tetapi lebih dari itu, ia bertanggung jawab akan keseluruhan perkembangan kepribadian siswa (Yoh. 10:10; 14:6). la harus mampu menciptakan proses belajar mengajar yang sedemikian rupa sehingga dapat merangsang siswa untuk belajar secara aktif dan dinamis dalam memenuhi kebutuhan dan menciptakan tujuan.

Peserta didik tidak pernah lepas dari belajar, baik di sekolah,lingkungan keluarga, maupun lingkungan masyarakat. Kemampuan afektif sangat diperlukan peserta didik dalam pendidikan. Perkembangan afektif merupakan salah satu aspek yang sangat penting dalam perkembangan peserta didik. Kita ketahui bahwa peserta didik merupakan objek yang berkaitan langsung dengan proses pembelajaran, sehingga perkembangan afektif sangat menentukan keberhasilan peserta didik dalam sekolah.

Ranah afektif berkenaan dengan sikap dan nilai. Sikap merupakan konsep psikologis yang kompleks, sikap berakar dalam perasaan. Sikap merupakan sebagai kecenderungan untuk bertindak secara suka atau tidak suka terhadap sesuatu objek. Sikap juga sebagai kumpulan hasil evaluasi seseorang terhadap objek, orang atau masalah tertentu. Sikap menentukan bagaimana kepribadian seseorang diekspresikan, oleh karena itu, melalui sikap seseorang kita dapat mengenal siapa orang itu sebenarnya.

Ranah afektif berkenaan dengan sikap dan nilai. Beberapa ahli mengatakan bahwa sikap seseorang dapat diramalkan perubahannya, bila seseorang telah memiliki penguasaan kognitif tingkat tinggi. Penilaian hasil belajar afektif kurang mendapat perhatian dari guru. Para guru lebih banyak menilai ranah kognitif semata-mata. Tipe hasil penilaian afektif tampak pada siswa dalam berbagai tingkah laku seperti perhatiannya terhadap pelajaran, disiplin, 
motivasi belajar, menghargai guru dan teman sekelas, kebiasaan belajar, dan hubungan sosial.

Sekalipun bahan pelajaran berisi ranah kognitif, ranah afektif harus menjadi bagian integral dari bahan tersebut dan harus tampak dalam proses belajar dan hasil belajar yang dicapai oleh siswa.

Kawasan afektif yaitu kawasan yang berkaitan dengan aspek-aspek emosional seperti perasaan, minat, sikap, kepatuhan terhadap moral dan sebagainya. Di dalamnya mencakup penerimaan (receiving/attending), sambutan(responding), tata nilai (valuing), pengorganisasian (organization), dan karakterisasi (characterization).

Dalam aspek ini peserta didik dinilai sejauh mana ia mampu menginternalisasikan nilai-nilai pembelajaran ke dalam dirinya. Aspek afektif ini erat kaitannya dengan tata nilai dan konsep diri. Dalam mata pelajaran Pendidikan Agama
Kristen, akhlak merupakan salah satu pelajaran yang tidak terpisahkan dari domain/aspek afektif.

Penilaian afektif (sikap) sangat menentukan keberhasilan peserta didik untuk mencapai ketuntasan dan keberhasilan dalam pembelajaran. Seorang peserta didik yang tidak memiliki minat terhadap mata pelajaran tertentu, maka akan kesulitan untuk mencapai ketuntasan belajar secara maksimal. Sedangkan peserta didik yang memiliki minat terhadap mata pelajaran, maka akan sangat membantu untuk mencapai ketuntasan pembelajaran secara maksimal.

Pendidikan pada umumnya mengupayakan pengembangan tiga aspek kepribadian peserta didik, yaitu kognitif, afektif,dan psikomotorik. Ketiga aspek tersebut sering di sama artikan dengan cipta, rasa, dan karsa. Istilah kognitif disebut juga sebagai penalaran, sedangkan afektif ekuivalen dengan budi pekerti,adapun 
psikomotorik sama dengan keterampilan jasmaniah.

Dengan efektivitas pembelajaran guru dapat mempengaruhi hasil belajar afektif siswa, yang lebih banyak berkenaan dengan perilaku dalam aspek berfikir atau intelektual. Seorang siswa dikatakan memiliki nilai afektif bilamana telah memenuhi beberapa kemampuan afektif. Tidak berhasilnya suatu tujuan pembelajaran bukan hanya dipengaruhi oleh bagaimana pengajaran yang diberikan oleh guru. Namun juga dapat dipengaruhi oleh keterbatasan kemampuan atau kemampuan yang kurang baik yang dimiliki oleh siswa.

Efektivitas pembelajaran perlu didukung oleh suasana dan lingkungan belajar yang memadai/kondusif. Oleh karena itu,guru harus mampu mengelola siswa, mengelola kegiatan pembelajaran, mengelola kegiatan pembelajaran dan mengelola sumber-sumber belajar. Menciptakan kelas yang efektif dengan peningkatan efektivitas proses pembelajaran tidak bisa dilaksanakan secara persia, melainkan harus menyeluruh mulai dari perencanaan/persiapan, pelaksanaan dan dan evaluasi.

Menurut Rusman dalam bukunya Model-model pembelajaran (2014, hh. 4-13) menyatakan 3 (tiga) upaya Efektivitas pembelajaran Guru yaitu; perencanaan, pelaksanaan, dan evaluasi.

\section{Perencanaan/ pembelajaran}

persiapan

Perencanaan proses pembelajaran meliputi silabus dan rencana pelaksanaan pembelajaran (RPP) yang memuat identitas mata pelajaran, standar kompetensi (SK), kompetensi dasar (KD), indikator pencapaian kompetensi, tujuan pembelajaran, materi ajar, alokasi waktu, alokasi waktu, metode pembelajaran, kegiatan pembelajaran, penilaian hasil belajar, dan sumber belajar. 
a) Silabus

Silabus sebagai acuan pengembangan rencana pelaksanaan pembelajaran memuat identitas mata pelajaran atau tema pelajaran, standar kompetensi, kompetensi dasar, materi pembelajaran, kegiatan pembelajaran, indikator pencapaian kompetensi, penilaian, alokasi waktu dan sumber belajar. Silabus dikembangkan oleh satuan pendidikan berdasarkkan standar isi dan standar kompetensi lulusan, serta panduan penyusunan kurikulum tingkat satuan pendidikan, Dalam pelaksanaanya, pengembangan silabus dapat dilakukan oleh para guru secara mandiri atau berkelompok dalam sebuah sekolah.

Prinsip

Pengembangan

\section{Silabus}

a. IImiah. Keseluruhan materi dan kegiatan yang menjadi muatan dalam silabus harus benar dan dapat dipertanggungjawabkan secara keilmuan.

b. Relevan. Cakupan, kedalaman, tingkat kesukaran dan urutan penyajian materi dalam silabus sesuai dengan tingkat perkembangan fisik, intelektual, sosial, emosional, dan spritual peserta didik.

c. Sistematis. Komponenkomponen silabus saling berhubungan secara fungsional dalam mencapai kompetensi.

d. Konsisten. Adanya hubungan yang konsisten (ajeg, taat asas) antara kompetensi dasar, indikator, materi pokok, pengalaman belajar, sumber belajar, dan sistem penilaian.

e. Memadai. Cakupan indikator, materi pokok, pengalaman belajar, sumber belajar, dan sistem penilaian cukup untuk 
menunjang pencapaian kompetensi dasar.

f. Aktual dan

Kontekstual. Cakupan indikator, materi pokok, pengalaman belajar, sumber belajar, dan sistem penilaian memperhatikan perkembangan ilmu, teknologi, dan seni mutakhir dalam kehidupan nyata, dan peristiwa yang terjadi.

g. Fleksibel. Keseluruhan komponen silabus dapat mengakomodasi keragaman peserta didik, pendidik, serta dinamika perubahan yang terjadi di sekolah dan tuntutan masyarakat.

h. Menyeluruh. Komponen silabus mencakup keseluruhan ranah kompetensi (kognitif, afektif, psikomotor).

\section{Unit Waktu Silabus}

a. Silabus mata pelajaran disusun berdasarkan seluruh alokasi waktu yang disediakan untuk mata pelajaran selama penyelenggaraan

pendidikan

d tingkat satuan pendidikan.

b. Penyusunan silabus memperhatikan alokasi waktu yang disediakan per semester, per tahun, dan alokasi waktu mata pelajaran lain yang sekelompok.

c. Implementasi pembelajaran per semester menggunakan penggalan silabus sesuai dengan Standar Kompetensi dan Kompetensi Dasar untuk mata pelajaran dengan alokasi waktu yang tersedia pada struktur kurikulum. Khusus untuk SMK/MAK menggunakan penggalan silabus berdasarkan satuan kompetensi.

\section{Komponen-Komponen}

\section{Silabus}


Silabus dalam Kurikulum

Tingkat Satuan Pendidikan terdiri dari beberapa komponen, sebagai berikut.

a. Standar Kompetensi Mata Pelajaran

Standar kompetensi mata pelajaran adalah batas dan arah kemampuan yang harus dimiliki dan dapat dilakukan oleh peserta didik setelah mengikuti proses pembelajaran suatu mata pelajaran tertentu, kemampuan yang dapat dilakukan atau ditampilkan siswa untuk suatu mat pelajaran, kompetensi dalam mata pelajaran tertentu yang harus dimiliki siswa, kemampuan yang harus dimiliki oleh Iulusan dalam dalam suatu mata pelajaran tertentu. Standar Kompetensi terdapat dalam Permen Diknas Nomor 22 Tahun
2006 tentang Standar Isi.

b. Kompetensi Dasar Kompetensi dasar adalah kemampuan minimal pada tiap mata pelajaran yang harus dicapai siswa. Kompetensi dasar dalam silabus berfungsi untuk mengarahkan guru mengenai target yang harus dicapai dalam pembelajaran.Misalnya, mampu menyelesaikan diri dengan lingkungan dan

sebagainya.Kompetensi Dasar terdapat dalam Permen Diknas Nomor 22 Tahun 2006 tentang Standar Isi.

c. Hasil Belajar

Hasil belajar adalah kemampuan siswa dalam memenuhi suatu tahapan pencapaian pengalaman belajar dalam suatu kompetensi 


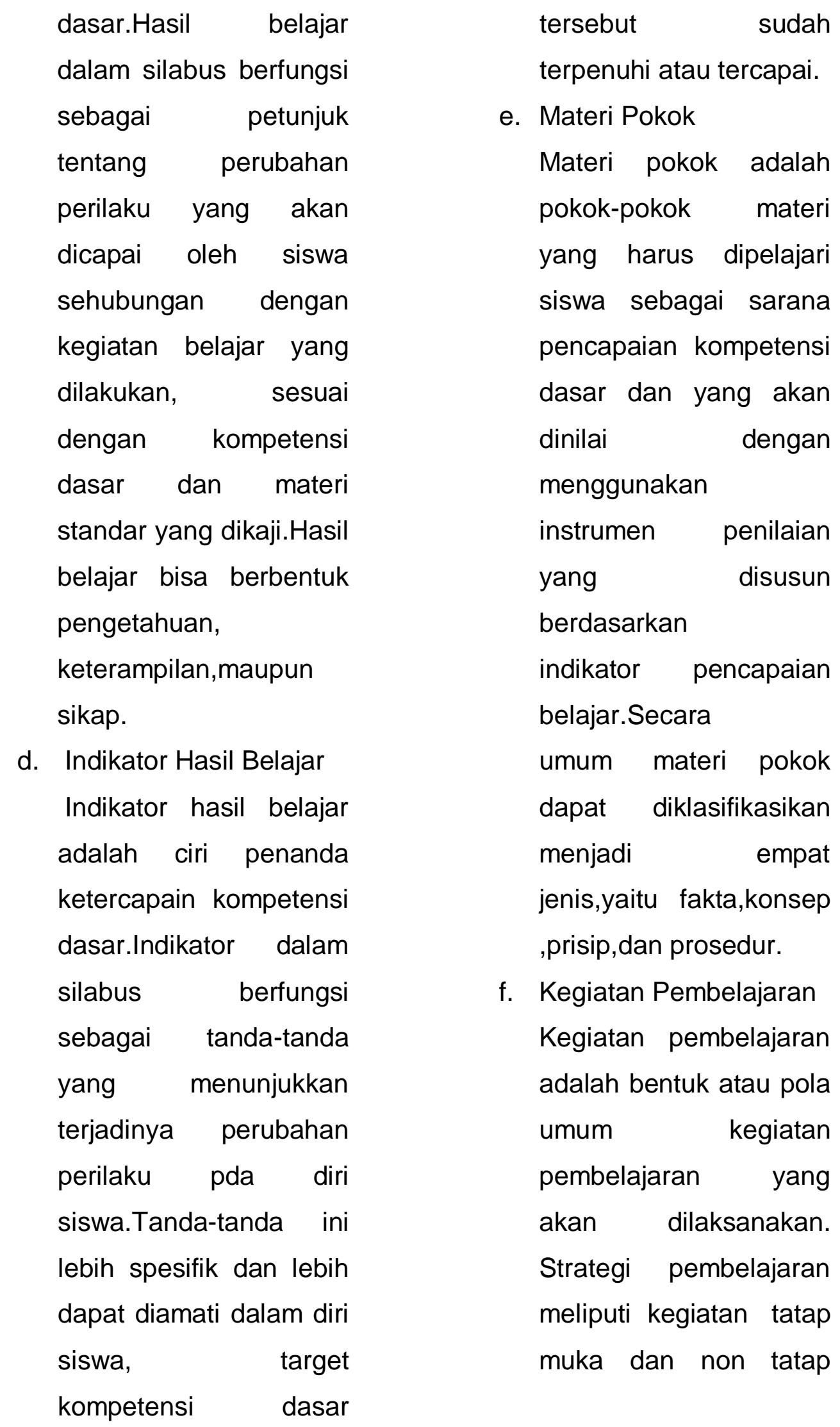


Munte, Pengaruh Efektifitas Pembelajaran Guru PAK terhadap Peningkatan Nilai Afektif Siswa Kasus: SMP Negeri 1 Pematangsiantar

muka (pengalaman

belajar).

dasar. Setiap guru pada satuan

g. Alokasi Waktu

Alokasi waktu adalah waktu yang diperlukan

untuk menguasai

masing-masing

kompetensi dasar.

pendidikan

berkewajiban

menyusun rencan pelaksanaan

pembelajaran secara lengkap

dan sistematis agar pembelajaran

berlangsung secara secara

interaktif, inspiratif,

h. Adanya Penilaian

Penilaian adalah jenis, bentuk, dan instrumen yang digunakan untuk mengetahui atau mengukur keberhasilan belajar siswa.

i. Sarana dan Sumber

Belajar

Sarana dan sumber belajar adalah sarana dan sumber belajar yang digunakan dalam proses belajar mengajar.

\section{Komponen \\ Pelaksanaan Pembelajaran}

Rencana

b) Rencana Pelaksanaan Pembelajaran (RPP)

Rencana Pelaksanaan

Pembelajaran dijabarkan dari silabus untuk mengarahkan kegiatan belajar siswa dalam upaya mencapai kompetensi

1. Identitas Mata Pelajaran Identitas mata pelajaran, meliputi satuan pendidikan, kelas, semester, program keahlian, mata pelajaran atau tema pelajaran, serta jumlah pertemuan. 
2. Standar Kompetensi

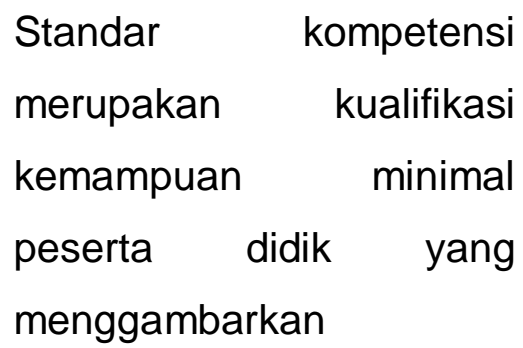

penguasaan pengetahuan, siskap, dan terampil yang diharapkan dicapai pada setiap kelas dan semester pada suatu mata pelajaran.

3. Kompetensi Dasar

Kompetensi dasar adalah sejumlah kemampuan yang harus dikuasai peserta didik dalam mata pelajaran tertentu sebagai rujukan penyusunan indikator kompetensi dalam suatu pelajaran

4. Indikator Pencapaian Kompetensi Indikator kompetensi adalah perilaku yang dapat diukur atau di observasi untuk menunjukkan ketercapaian kompetensi dasar tertentu yang menjadi acuan penelitian mata pelajaran. Indikator pencapaian kompetensi dirumuskan dengan menggunakan kata kerja operasional yang dapat diamati dan diukur, yang mencakup pengetahuan, sikap, dan ketrampilan.

5. Tujuan Pembelajaran Tujuan pembelajaran menggambarkan proses dan hasil belajar yang diharapkan dicapai oleh peserta didik sesuai dengan kompetensi dasar.

6. Materi Ajar Materi ajar memuat fakta, konsep, prinsip, dan prosedur yang relevan dan ditulis ditulis dalam bentuk butir-butir sesuai dengan rumusan indikator pencapaian kompetensi.

7. Alokasi Waktu

Alokasi waktu ditentukan sesuai dengan keperluan untuk pencapaian kompetensi dasar dan beban belajar.

8. Metode Pembelajaran Metode pembelajaran digunakan oleh guru untuk 


$$
\begin{aligned}
& \text { mewujudkan suasana } \\
& \text { belajar dan proses } \\
& \text { pembelajaran agar peserta } \\
& \text { didik mencapai } \\
& \text { kompetensi dasar atau } \\
& \text { seperangkat indikator yang } \\
& \text { telah ditetapkan. Pemilihan } \\
& \text { metode pembelajaran } \\
& \text { disesuaikan dengan situasi } \\
& \text { dan kondisi peserta didik, } \\
& \text { serta karakteristik dari } \\
& \text { setiap indikator dan } \\
& \text { kompetensi yang hendak } \\
& \text { dicapai pada setiap mata } \\
& \text { pelajaran. }
\end{aligned}
$$

9. Kegiatan Pembelajaran

a. Pendahuluan

Pendahuluan

merupakan kegiatan

awal suatu pertemuan

pembelajaran yang

ditujukan untuk

membangkitkan

motivasi dan

memfokuskan

perhatian peserta didik

untuk berpartisipasi

aktif dalam proses

pembelajaran.

b. Inti
Kegiatan inti

merupakan proses

pembelajaran untuk

mencapai kompetensi

dasar. Kegiatan

pembelajaran

dilakukan secara

interaktif, inspiratif, menyenangkan,

menantang,

memotivasi peserta

didik untuk

berpartisipasi aktif,

serta memberikan

ruang yang cukup bagi

prakarsa, kreativitas,

dan kemandirian

sesuai dengan bakat,

minat dan

perkembangan fisik,

serta pisikologis

peserta didik.

c. Penutup

Penutup merupakan

kegiatan yang

dilakukan untuk

mengakhiri aktivitas

pembelajaran yang

dapat dilakukan dalam

bentuk rangkuman atau

kesimpulan, penilaian, 
refleksi, umpan balik, serta tindak lanjut.

1. Penilaian hasil belajar

Prosedur dan instrument penilaian proses dan hasil belajar disesuaikan dengan indikator pencapaian

kompentensi dan mengaju pada standart penilaian.

2. Sumber belajar Penentuan sumber belajar didasarkan pda standart kompentensi dan kompetensi dasar, serta materi ajar, kegiatan

pembelajaran, dan indikator pencapaian kompetensi.

\section{Prinsip-prinsip Penyusunan} Rencana Pelaksanaan

\section{Pembelajaran}

a. Memerhatikan Perbedaan Individu Peserta Didik
Rencana Pelaksanaan Pembelajaran disusun dengan memerhatikan perbedaan jenis kelamin, kemampuan awal, tingkat intelektual, minat, motivasi belajar, bakat, potensi, kemampuan sosisl, emosi, gaya belajar, kebutuhan khusus, kecepatan belajar, latar belakang budaya, norma, nilai, dan lingkungan peserta didik.

b. Mendorong Partisipasi aktif Peserta Didik

Proses pembelajaran dirancang dengan berpusat pada peserta didik untuk mendorong motivasi, minat, kreativitas, inisiatif, inspirasi , kemandirian, dan semangat belajar.

c. Mengembangkan budaya membaca dan menulis

Proses pembelajaran dirancang mengembangakan kegemaran membaca, pemahaman beragam bacaan, dan berekspresi dalam berbagai bentuk tulisan. 
d. Memberikan umpan balik dan tindaklanjut

Rencana pelaksanan pembelajran memuat rancangan program pemberian umpan balik positif, penguatan, pengayaan dan remedial.

e. Keterkaitan dan keterpaduan

Rencana pelaksanaan pembelajaran disusun dengan memerhatikan keterkaitan dan keterpaduan antara standart kompetensi, kompetensi dasar, materi pembelajaran, kegiatan pembelajran, indikator, pencapaian kompetensi, penilaian dan sumber belajar dalam satu keutuhan pengalaman belajar. Rencana pelaksanaan pembelajaran disusun dengan mengakomodasikan pembelajaran tematik, keterpaduan lintas mata pelajaran, lintas aspek belajar dan keragaman budaya.

f. Menerapkan teknologi informasi dan komunikasi
Rencana pelaksanaan pembelajaran disusun dengan mempertimbangkan penerapan teknologi informasi dan komunikasi secara terintegrasi, sistematis, dan efektif sesuai dengan situasi dan kondisi.

\section{Tujuan dan Fungsi RPP}

$$
\text { Tujuan }
$$

rencana

pelaksanaan pembelajaran adalah untuk:

1. mempermudah, memperlancar dan meningkatkan hasil proses belajar mengajar.

2. dengan menyusun rencana pembelajaran secara profesional, sistematis dan berdaya guna, maka guru akan mampu melihat, mengamati, menganalisis, dan memprediksi program pembelajaran sebagai kerangka kerja yang logis dan terencana.

Sementara itu, fungsi rencana pembelajaran adalah 
sebagai acuan bagi guru untuk melaksanakan kegiatan belajar mengajar (kegiatan pembelajaran ) agar lebih terarah dan berjalan secara efektif dan efisien. Dengan kata lain rencana pelaksanaan pembelajaran berperan sebagai skenario proses pembelajaran.

Oleh karena itu, rencana pelaksanaan pembelajaran hendaknya bersifat luwes ( fleksibel ) dan member kemungkinan bagi guru untuk menyesuaikan dengan respon siswa dalam proses pembelajaran yang sesungguhnya.

\section{Pelaksanaan pembelajaran}

Sebelum guru PAK melakuakan pelaksanaan pembelajaran ada baiknya mempersiapakan persyaratan pelaksananaan proses

pembelajaran. Beban kerja guru mencakup kegiatan pokok yaitu merencanakan kegiatan pembelajaran, menilai hasil pembelajaran, membimbing dan melatih peserta didik, serta melaksanakan tugas tambahan.

Buku teks pelajaran yang akan digunakan oleh sekolah dipilih melalui rapat guru dengan pertimbangan komite sekolah dari buku-buku teks pelajaran yang ditetapkan oleh menteri. Selain buku teks pelajaran guru menggunakan buku panduaan guru, buku pengayaan, buku refrensi dan sumber belajar lainnya. Guru membiasakan peserta didik menggunakan buku-buku dan sumber belajar lain yang ada di perpustakaan sekolah.

Dengan itu dalam pengelolaan kelas guru mengatur tempat duduk sesuai dengan karakteristik peserta didik dan mata pelajaran, serta aktivitas pembelajaran yang akan dilakukan. Volume dan intonasi suara guru dalam proses pembelajaran harus dapat didengar dengan baik oleh peserta didik, tuturkata guru, santun dan dapat dimengerti oleh peserta didik. Guru menyesuaikan materi pelajaran 
dengan kecepatan dan kemampuan belajar peserta didik, guru menciptakan ketertiban, kedisiplinan, kenyamanan, keselamatan, dan kepatuhan pada peraturan dalam penyelenggaraan proses pembelajaran.

Guru memberi penguatan dan umpan balik terhadap respon dan hasil belajar peserta didik selama prose pembelajaran berlangsung. Guru menghargai peserta didik tanpa memandang latarbelakang agama, suku, jenis kelamin dan status sosisl ekonomi, guru menghargai peserta didik, guru memakai pakain yang sopan, bersih dan rapi. Pada tiap awal semester, guru menyampaikan silabus pada pelajaran yang dipersiapkan. Guru memulai dan mengakhiri proses pembelajaran sesuai dengan waktu yang dijadwalkan.

\section{Evaluasi}

Penilaian dilakukan oleh guru terhadapleasidngemibiel bjerlaumbumtglarmengukur tingka dan terprogram dengan menggunakan tes dan non tes dalam bentuk tertulis atau lisan, pengamatan kinerja, pengukuran sikap, penilaian hasil karya berupa tugas, proyek dan produk, portofolio, serta penilaian diri. Penilaian hasil pembelajaran mengguanakan standart penilaian pendidikan dan panduan penilaian kelompok mata pelajaran.

Nilai afektif berkenaan dengan hasil belajar intelektual yang terdiri dari enam aspek, yakni pengetahuan atau ingatan, pemahaman, aplikasi,analisis, sintesis dan evaluasi. Kedua aspek pertama disebut kognitif tingkat rendah dan ke empat aspek berikutnya termasuk kognitif tingkat tinggi, (Sudjana, 2014, h. 22)

\section{Peningkatan Nilai Afektif Siswa}

Ada 3 tingkatan dalam domain Afektif, Sudjana (2009, hh. 29-30) antara lain:

\section{Receiving / Attending} dengan kesediaan atau kemauan siswa untuk ikut dalam fenomena atau stimulasi khusus (kegiatan dalam kelas, baca buku dan 
sebagainya).dihubungkan

dengan pengeajaran jenjang ini berhubungan dengan

menimbukkan, mempertahankan, dan mengarahkan perhatiana siswa. Sedangkan perumusan untuk membuat soalnya yaitu menanyakan, menjawab, menyebutkan, memilih, mengidentifikasi, memberikan, mengikuti, menyeleksi, menggunakan, dan lain-lain.

Kepekaan seseorang
dalam menerima rangsangan (
stimulus) dari luar yang datang
kepada dirinya dalam bentuk
masalah situasi, gejala dan lain-
lain. Termasuk dalam jenjang ini
misalnya adalah : kesadaran dan
keinginan untuk menerima
stimulus, mengontrol dan
menyeleksi gejala-gejala tau
rangsangan yang datang dari
luar.

Receiving atau attending juga sering diberi pengertian sebagai kemauan untuk memeperhatikan suatau kegiatan atau suatu objek. Pada jenjang ini peserta didik dibina agar mereka bersedia menerima nilai atau nila- nilai yang diajarkan kepada mereka, dan mereka mau menggabungkan diri ke dalam nilai itu atau mengidentifikasikan diri dengan nilai itu . contoh hasil belajar afektif jenjang receiving, misalnya : peserta didik bahwa disiplin wajib ditegakkan, sifat malas dan tidak disiplin harus disingkirkan jauh-jauh.

\section{Responding} atau jawaban

Kemampuan ini bertalian dengan partisipasi siswa. Pada tingkat ini, siswa hanya menghadiri sesuatu fenomena tertentu tetapi juga mereaksi terhadapnya dengan salah satu cara. Hasil belajar dalam jenjang ini dalapt menekankan kemauan untuk menjawab. Sedangkan perumusan bentuk soalnya adalah menjawab, melakukan, menulis, menceritakan, membantu, melaporkan, dan sebagainya.

Mengandung arti adanya partisipasi aktif. Jadi kemampuan menanggapi adalah kemampuan 
Munte, Pengaruh Efektifitas Pembelajaran Guru PAK terhadap Peningkatan Nilai Afektif Siswa Kasus: SMP Negeri 1 Pematangsiantar

yang dimiliki oleh sesorang untuk mengikutsertakan dirinya secara aktif dalam fenomena tertentu yang membuat reaksi terhadapnya salah satu cara. jenjang ini lebih tinggi daripada jenjang receiving. Contoh hasil belajar ranah afektif responding misalanya : peserta didik tumbuh hasratnya untuk mempelajarinya lebih jauh atau menggali lebih dalam lagi, ajaran-ajaran kristen tentang kedisplinan.

3. Karakterisasi dengan suatu nilai atau kompleks nilai

Pada jenjang ini individu memiliki system nilai yang mengontrol tingkah lakunya untuk suatu waktu yang cukup lama sehingga membentuk karakteristik "pola hidup". Jadi, tingkah lakunya menetap, konsisten, dan dapat diramalkan. Hasil belajar meliputi sangat banyak kegiatan, tapi menekankan lebih besar diletakkan pada kenyataan bahwa tingkah laku itu menjadi ciri khas atau karakteristik siswa itu.

Keterpaduan semua sistem nilai yang telah dimiliki oleh seseorang , yang mempengaruhi pola kepribadian dan tingkahlakunya. Disini prosesonternalisasi nilai telah menempati tempat tertinggi dalam suatu hirarki nilai. Nilai itu telah tertanam secara konsisten pada sistemnya dan telah mempengaruhi emosinya. Ini adalah merupakan tingkat efektif tertinggi, karena sikap batin peserta didik telah benar-benar bijaksana. la telah mimiliki phyloshopphy of life yang mapan. Jadi pada jenjang ini peserta didik telah memiliki sistem nilai yang telah mengontrol tingkah lakunya untuk suatu waktu yang lama, sehingga membantu karakteristik "pola hidup" tingkah lakunya menetap, konisten dan dapat diramalkan. Contoh hasil belajar afektif pada jenjang ini adalah siswa telah memiliki kebulatan sikap wujudnya peserta didik menjadikan perintah Allah menyangkut disiplin, baik 
kedisiplinan sekolah, di rumah, maupun di tengah-tengah kehidupan masyarakat.

Pemikiran atau perilaku harus memiliki dua kriteria untuk diklasifikasikan sebagai ranah afektif (Anderson, 1981, h. 4).

1. Perilaku melibatkan perasaan dan emosi seseorang

2. Perilaku harus tipikal perilaku seseorang.

Kriteria lain yang termasuk ranah afektif adalah intensitas, arah dan target. Intensitas menyatakan derajat atau kekuatan dari perasaan , beberapa perasaan lebih kuat dari yang lain, misalanya m: cinta lebih kuat dari senag atau sukar. Sebagian orang kemumgkinan memiliki perasaan yang lebih kuat dibanding yang lain. Arah perasaan berkaitan dengan orientasi positif atau negatif dari perasaan yang menunjukkan apakah perasaan itu baik atau baik. Misalnya senang pada pelajaran dimaknai positif, sedang kecemasan dimaknai negatif. Bila intensitas dan arah perasaan ditinjau bersama sama, maka karakteristik afektif berada dalam suatu skala yang kontimun. Target mengacu pada objek, aktivitas, atau ide sebagai arah dari perasaan. Bila kecemasan merupakan karakteristik afektif yang ditinjau, ada beberapa kemungkinan target. Peserta didik mungkin bereaksi terhadap sekolah, matematika, situasi sosial, atau pembelajaran. Tiap unsur ini bisa merupakan target dari kecemasan. Kadang-kadang target ini diketahui oleh seseorang namun kadangkadang tidak diketahui. Seringkali peserta didik merasa cemas bila menghadapi tes di kelas. Peserta didik tersebut cenderung sadar bahwa target kecemasannya adalah tes.

Ada 5 tipe karakteristik afektif yang penting berdasarkan tujuannya, yaitu sikap, minat, konsep diri, nilai, dan moral.

1. Sikap

Sikap merupakan suatu kencendrungan untuk bertindak secara suka atau tidak suka 
terhadap suatu objek. Sikap dapat dibentuk melalui cara mengamati dan menirukan sesuatu yang positif, kemudian melalui penguatan serta menerima informasi verbal. Perubahan sikap dapat diamati dalam proses pembelajaran, tujuan yang ingin dicapai, keteguhan, dan konsistensi terhadap sesuatu. Penilaian sikap adalah penilaian yang dilakukan untuk mengetahui sikap peserta didik terhadap mata pelajaran, kondisi pembelajaran, pendidik, dan sebagainya.

Menurut Fishbein dan Ajzen (1975) sikap adalah suatu predisposisi yang dipelajari untuk merespon secara positif atau negatif terhadap suatu objek, situasi, konsep, atau orang. Sikap peserta didik terhadap objek misalnya sikap terhadap sekolah atau terhadap mata pelajaran. Sikap peserta didik ini penting untuk ditingkatkan (Popham, 1999). Sikap peserta didik terhadap mata pelajaran, misalnya bahasa Inggris, harus lebih positif setelah peserta didik mengikuti pembelajaran bahasa Inggris dibanding sebelum mengikuti pembelajaran. Perubahan ini merupakan salah satu indikator keberhasilan pendidik dalam melaksanakan proses pembelajaran. Untuk itu pendidik harus membuat rencana pembelajaran termasuk pengalaman belajar peserta didik yang membuat sikap peserta didik terhadap mata pelajaran menjadi lebih positif.

2. Minat

Menurut Getzel (1966), minat adalah suatu disposisi yang terorganisir melalui pengalaman yang mendorong seseorang untuk memperoleh objek khusus, aktivitas, pemahaman, dan keterampilan untuk tujuan perhatian atau pencapaian. Sedangkan menurut kamus besar bahasa Indonesia (1990, h. 583), minat atau keinginan adalah kecenderungan hati yang tinggi terhadap sesuatu. Hal penting pada minat adalah intensitasnya. Secara umum minat termasuk karakteristik afektif yang memiliki intensitas tinggi. 
Penilaian minat dapat digunakan untuk:

a. Mengetahui minat peserta didik sehingga mudah untuk pengarahan dalam pembelajaran,

b. Mengetahui bakat dan minat peserta didik yang sebenarnya,

c. Pertimbangan penjurusan dan pelayanan individual peserta didik,

d. Menggambarkan keadaan langsung di lapangan/kelas,

e. Mengelompokkan peserta didik yang memiliki minat sama,

f. Acuan dalam menilai kemampuan peserta didik secara keseluruhan dan memilih metode yang tepat dalam penyampaian materi,

g. mengetahui tingkat minat peserta didik terhadap pelajaran yang diberikan pendidik,

h. Bahan pertimbangan menentukan program sekolah, i. Meningkatkan motivasi belajar peserta didik.

3. Konsep Diri

Konsep diri adalah evaluasi yang dilakukan individu terhadap kemampuan dan kelemahan yang dimiliki. Target, arah, dan intensitas konsep diri pada dasarnya seperti ranah afektif yang lain. Target konsep diri biasanya orang tetapi bisa juga institusi seperti sekolah. Arah konsep diri bisa positif atau negatif, dan intensitasnya bisa dinyatakan dalam suatu daerah kontinum, yaitu mulai dari rendah sampai tinggi.

Konsep diri ini penting untuk menentukan jenjang karir peserta didik, yaitu dengan mengetahui kekuatan dan kelemahan diri sendiri, dapat dipilih alternatif karir yang tepat bagi peserta didik. Selain itu informasi konsep diri penting bagi sekolah untuk memberikan motivasi belajar peserta didik dengan tepat.

4. Nilai

Nilai menurut Rokeach (1968) merupakan suatu 
keyakinan tentang perbuatan, tindakan, atau perilaku yang dianggap baik dan yang dianggap buruk. Selanjutnya dijelaskan bahwa sikap mengacu pada suatu organisasi sejumlah keyakinan sekitar objek spesifik atau situasi, sedangkan nilai mengacu pada keyakinan.

Target nilai cenderung menjadi ide, target nilai dapat juga berupa sesuatu seperti sikap dan perilaku. Arah nilai dapat positif dan dapat negatif. Selanjutnya intensitas nilai dapat dikatakan tinggi atau rendah tergantung pada situasi dan nilai yang diacu.

\section{Moral}

$$
\text { Piaget dan Kohlberg }
$$
banyak membahas tentang perkembangan moral anak. Namun Kohlberg mengabaikan masalah hubungan antara judgement moral dan tindakan moral. la hanya mempelajari prinsip moral seseorang melalui penafsiran respon verbal terhadap dilema hipotetikal atau dugaan, bukan pada bagaimana sesungguhnya seseorang bertindak.
Moral berkaitan dengan perasaan salah atau benar terhadap kebahagiaan orang lain atau perasaan terhadap tindakan yang dilakukan diri sendiri. Misalnya menipu orang lain, membohongi orang lain, atau melukai orang lain baik fisik maupun psikis. Moral juga sering dikaitkan dengan keyakinan agama seseorang, yaitu keyakinan akan perbuatan yang berdosa dan berpahala. Jadi moral berkaitan dengan prinsip, nilai, dan keyakinan seseorang.

\section{METODOLOGI PENELITIAN}

Jenis metode penelitian adalah deskriftif kuantitatif, penelitian deskriptif adalah metode dalam penelitian kasus sekelompok manusia, suatu sistem pemikiran, ataupun suatu kelas peristiwa pada masa sekarang yang bertujuan untuk membuat deskripsi, gambaran atau lukisan secara sistematis, faktual dan akurat mengenai fakta-fakta, sifat-sifat serta hubungan antara fenomena yang diselidiki. Selain itu Amirman (1993, h. 21) 
menjelaskan keadaan sekarang, menentukan hubungan antara variabel dan fenomena yang diteliti.

Dan Arikunto menyatakan bahwa penelitian kuantitatif memiliki kejelasan unsur yang dirinci sejak awal, langkah penelitian yang sistematis menggunakan sampel yang hasil penelitiannya diberlakukan untuk populasi, memiliki hipotesis, memiliki desain jelas dengan langkah-langkah penelitian dan hasil yang diharapkan, memerlukan pengumpulan data yang dapat mewakili serta ada analisis data yang dilakukan setelah semua data terkumpul.

Sampel adalah bagian terkecil dari populasi. Dan penarikan sampel tidak dilakukan dengan sembarangan, sebab sampel harus dapat mewakili seluruh populasi artinya segala karakteristik populasi yang akan diteliti hendaknya tercermin dalam sampel yang di ambil atau disebut refresentatif (Sudjana 1984, h. 6).
Sampel adalah bagian dari jumlah dan karakteristik yang dimiliki oleh populasi tersebut (Sugiono 2009, h. 118). Sudjana (2005, h. 6) juga mengatakan "sampel adalah bagian terkecil dari populasi". Sampel harus dapat mewakili seluruh populasi, artinya segala karakteristik populasi yang akan diteliti hendaknya representatif sifatnya dari keseluruhan. Sampel diambil dengan menggunakan cara tertentu. Sampel harus refresentatif dari keseluruhan populasi yang ada. Siswa/i kelas VIII SMP Negeri 1 Pematangsiantar. khususnya yang beragama Kristen Protestan. diperoleh data sebanyak 105 siswa, laki-laki 47 orang dan perempuan 58 orang. Melihat banyaknya objek penelitian ini, maka untuk menentukan besarnya sampel dapat digunakan dengan Rumus Cochran. Maka jumlah sampel adalah 45. 
PEMBAHASAN PENELITIAN

Berdasarkan hasil analisis data yang diperoleh dari lapangan penelitian SMP Negeri 1 Pematangsiantar hasil tersebut dimasukkan ke dalam kriteria pengujian, maka dapat ditemukan bahwa Efektivitas Pembelajaran Guru PAK sangat berpengaruh terhadap Peningkatan Nilai Afektif Siswa.

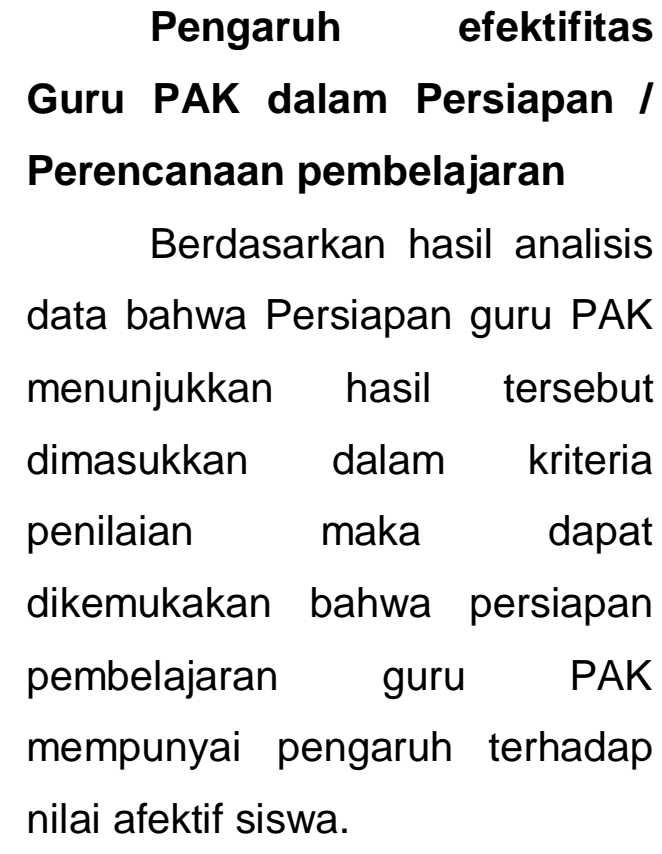

Pengaruh efektifitas

Guru PAK dalam Pelaksanaan Pembelajaran

Berdasarkan

hasil

analisis data bahwa pelaksanaan pembelajaran guru PAK menunjukkan hasil setelah

$\begin{array}{llr}\text { dimasukkan } & \text { dalam } & \text { kriteria } \\ \text { penilaian } & \text { maka } & \text { dapat } \\ \text { dikemukakan } & & \text { bahwa }\end{array}$
pelaksanaan pembelajaran guru PAK mempunyai pengaruh terhadap nilai afektif siswa.

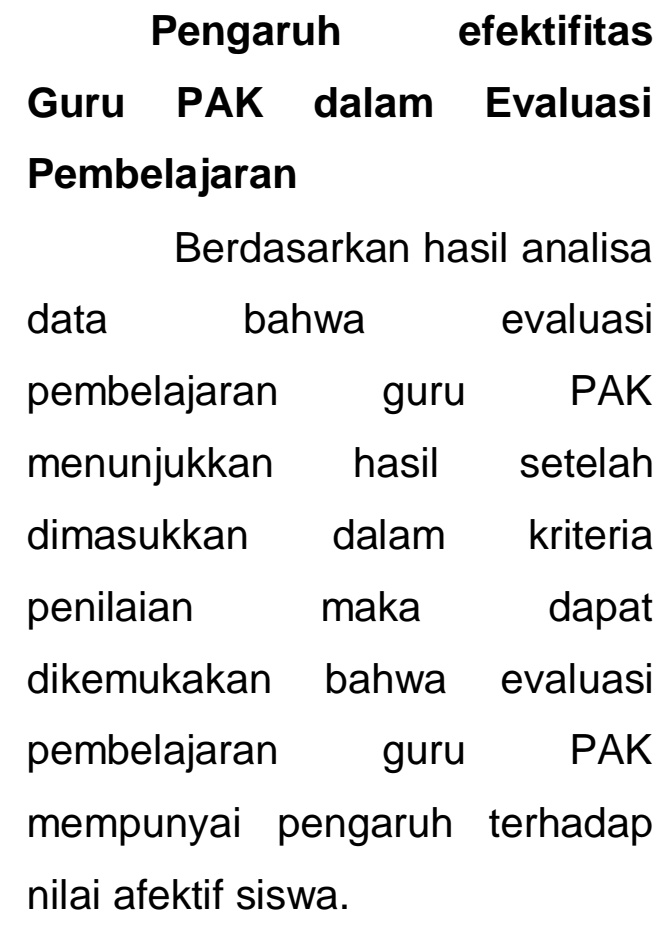
Hasil Peningkatan Nilai Afektif Siswa

Berdasarkan hasil analisis data peningkatan nilai afektif siswa yang diperoleh dari lapangan menunjukkan hasil setelah dimasukkan ke dalam kriteria pengujian, maka dapat dikemukakan bahwa Efektifitas pembelajaan guru PAK berpengaruh Terhadap peningkatan nilai afektif siswa Di 
$\begin{array}{lrr}\text { SMP } & \text { NEGERI } & 1 \\ \text { Pematangsiantar. } & \\ & \\ & \text { Berdasarkan data yang }\end{array}$ diperoleh dari lapangan penelitian menunjukkan bahwa :

1. Persiapan/Perencanaan pembelajaran oleh guru Pendidikan Agama Kristen menunjukkan pengaruh terhadap peningkatan nilai afektif siswa, sehingga hipotesis pertama dapat diterima.

2. Pelaksanaan pembelajaran oleh guru Pendidikan Agama Kristen menunjukkan pengaruh terhadap peningkatan nilai afektif siswa, sehingga hipotesis kedua dapat diterima.

3. Evaluasi pembelajaran oleh guru Pendidikan Agama Kristen menunjukkan pengaruh terhadap peningkatan nilai afektif siswa, sehingga hipotesis ketiga dapat diterima.

Hasil penelitian secara menyeluruh membuktikan diterimanya hipotesis tersebut
dengan keragaman yang berbeda-beda sesuai dengan tujuan penelitian.

\section{KESIMPULAN DAN SARAN \\ Secara umum, hasil} penelitian ini memperlihatkan bahwa pengaruh Efektifitas Pembelajaran Guru PAK melalui perencanaan pembelajaran , pelaksanaan pembelajaran, dan evaluasi pembelajaran mempunyai pengaruh terhadap Nilai Afektif Siswa. Hal ini terlihat dari perhitungan koefisien korelasi, uji signifikansi korelasi, uji determinasi, uji regresi linier sederhana, uji independen dan uji kelinieran regresi.

$\begin{array}{cr}\text { Secara Khusus } & \text { hasil } \\ \text { penelitian di } & \text { atas } \\ \text { memperlihatkan } & \text { bahwa }\end{array}$

Efektivitas Pembelajaran Guru PAK memiliki pengaruh terhadap peningkatan Nilai Afektif Siswa dengan berbagai aspek yang dilakukan yaitu :

a. Persiapan / Perencanaan guru dalam proses pembelajaran memberikan 
Munte, Pengaruh Efektifitas Pembelajaran Guru PAK terhadap Peningkatan Nilai Afektif Siswa Kasus: SMP Negeri 1 Pematangsiantar

pengaruh terhadap Nilai Afektif Siswa.

b. Pelaksanaan dalam proses pembelajaran memberikan pengaruh terhadap Nilai Afektif Siswa.

c. Evaluasi dalam proses pembelajaran memberikan pengaruh terhadap Nilai Afektif Siswa.

\begin{tabular}{cc}
\multicolumn{2}{c}{ Berdasarkan hasi } \\
penelitian yang telah
\end{tabular} dikemukakan menunjukkan hasil yang baik, akan tetapi perlu adanya tindak lanjut pada masa mendatang. Adapun beberapa saran yang akan diberikan antara lain : a. Hendaknya guru-guru Pendidikan Pgama Kristen semakin meningkatkan efektifitas pembelajarannya setiap melaksanakan

pembelajaran guna meningkatkan nilai-nilai afektif siswa.

b. Hendaknya siswa/i SMP Negeri 1 Pematangsiantar khususnya yang beragama Kristen Protestan mampu meningkatkan Nilai Afektif Siswa yang lebih baik sesuai dengan Visi dan misi sekolah untuk menjadikan sekolah yang bermutu dan berkualitas di Negeri ini.

Aunurrahman, (2012). Belajar dan Pembelajaran, Bandung : ALFABETA.

B. Uno, Hamzah, (2010). Perencanaan Pembelajaran, Jakarta : Bumi Aksara.

Daryanto, (2012). Konsep Pembelajaran Kreatif, Yogyakarta : Gava Media. 
Djamarah, S. B., Strategi Belajar Mengajar. Jakarta : Rineka Cipta.

Hamalik, O. (2005). Metode Belajar dan Kesulitankesulitan Belajar, Bandung, TARSITO.

Mulyasa, (2011). Menjadi Guru Profesional, Bandung : ROSDA.

Pidarta, M. (2009). Landasan Kependidikan Stimulus IImu Pendidikan Bercorak Indonesia, Jakarta: Rineka Cipta.

Pulungan, I. (2016). Ensiklopedi Pendidikan, Medan : LARISPA.

Purwanto, (2011). Evaluasi Hasil Belajar, Yogyakarta : Pustaka Pelajar.
Rusman, (2014). Model-model

Pembelajaran Mengembangkan Profesionalisme Guru, Jakarta: Rajawali Pers.

Sanjaya, W. (2006). Strategi Pembelajaran, Jakarta : KENCANA.

Sudjana, (1995). Penilaian Hasil Proses Belajar Mengajar, Bandung : Rosda Karya.

Yaumi, M. (2013) Prinsip-prinsip Desain Pembelajaran, Jakarta : KENCANA.

Enklaar, H. (2011). Pendidikan Agama Kristen, Jakarta : BPK Gunung Mulia.

(2005). Kamus Besar Bahasa Indonesia, Jakarta : Pustaka Poenix 